\title{
Dear colleagues!
}

We present you the proceedings VII of the International scientific conference "Problems of Complex Development of Georesources" which has taken place on September 25-27, 2018 in Khabarovsk city. They contain new results of basic and applied researches in area: geotechnological and geomechanical problems of development of a subsoil; problems of complex processing of mineral raw materials and new technologies of mineral processing; geoenvironmental and economic problems of subsurface use; strategic problems of mineral and raw and mining complexes.

A number of topics are discussed in the of the conference. Some of them are creation of new and increase in efficiency of the applied technologies of development, including nonconventional georesources; creation of new and improvement of the current methods of effective and complex extraction of useful components from refractory ores, alluvial materials and tailing dumps; reproduction, rational and complex use and preservation of a subsoil of Earth at development of active stocks and expected resources of natural and technogenic ore and alluvial deposits of precious metals, including georesources of cryogenic zony; estimation of influence of natural and technogenic factors on an intense and dynamic condition of burst hazard rock massif; estimation of regional geodynamic features of ore areas of the Far East of Russia and neighbouring territories; creations of methodical bases of complex monitoring of geo-media, including located in undermined and urbanized territories; development of technologies of rock destruction, including their explosive crushing; substatntiation of strategy of development for mineral different types of mineral resources according regional aspects and mining complexes and areas; increases in social and economic efficiency of environmental management with a growth of competitiveness of subsoil users in the world market of raw materials; creations of effective methods of the solution of environmental problems at development of mineral raw material resources.

The leading scientists and research specialists, representatives of universities of mining-and-geological profile, specialists of mining enterprises, representatives of state structure and other organizations from Russia, Germany, Australia, Japan, the USA, Kazakhstan, Kyrgystan and other countries have participated in the conference and prepared the reports.

Extensive geography of participants reflects both complexity, importance, relevance of the discussed scientific and technological, innovative mining problems and emphasizes the great interest of the mining community to the held conference which has become traditional.

Organizing committee of the conference hope that the materials will be useful to a wide range of scientists and practicians in the field of mining and will provide rational development and use of the Earth subsoil for the development and prosperity of the states and people of the world.

The conference is held with financial support of the Russian Fund of Fundamental Research (grant No. 18-05-20073 G).

Chairman of the Organizing Committee VII International Scientific Conference "Problems of Complex Development of Georesources"

Director of the Mining Institute FEB RAS Prof. I.Yu. Rasskazov 